\title{
ACCUMULATION OF SOME HEAVY METALS IN HAIR, PLASMA AND MILK OF CATTLE AND BUFFALOES GRAZING BERSEEM OR REED PLANTS IN EGYPT
}

\author{
H.M.A. Gaafar
}

Animal Production Research Institute, Agricultural Research Center, Dokki, Egypt

\section{SUMMARY}

Twenty four dairy cows and buffaloes were divided in two locations with 6 dairy cows and 6 dairy buffaloes in each. The animals in the first location were fed on berseem irrigated by Nile water, while in the second location (Burullus Lake) they were kept on reed plants. The obtained results showed that the contents of heavy metals (lead, cadmium, copper, nikel, aluminum, arsenic and mercury) in reed plants were significantly higher $(P<0.05)$ than in berseem.

The concentrations of heavy metals in hair, plasma and milk of cattle and buffaloes grazing on reed plants were significantly higher $(P<0.01)$ than that in those fed berseem. Moreover, the concentrations of heavy metals in hair were significantly higher $(P<0.05)$ in cattle than buffaloes, while the concentrations of heavy metals in plasma and milk were significantly higher $(P<0.05)$ in buffaloes than cattle.

It could be concluded that grazing cattle and buffaloes on reed plants in Burullus Lake led to higher accumulation of heavy metals in their hair, plasma and milk, causing possible hazardous effect on human health.

Keywords: Heavy metals, reed plants, cattle, buffaloes, hair, plasma, milk

\section{INTRODUCTION}

Heavy metal concentration has increased in the air, soil and waters, especially in the cities and industrial areas. According to predictions based on research monitoring the changes of heavy metal concentrations in the soil and plants, heavy metals will probably become important environmental stress factors over the next decades (Pais, 1992). Heavy metal deposition in rural areas is sometimes a problem because of industrial and sewage sludge contamination and as a consequence, grazing animals particularly are exposed to pollutants deposited on pastures (Smith et al., 1991 and Pittia, 1992).

Mechanism of collecting, distribution, concentration and effects of heavy metals in plants cannot be generalized for the reason that they are exposed to heavy metals from air, water and soil (Webber, 1981; Fergusson, 1990; Ure and Berrow, 1982). High contents of heavy metals in soil can lead to their accumulation in plant tissues, inhibit or block their physiological functions or make them unusable for nutrition (Ure and Berrow, 1982). Mammary glands in cows are the most physiologically active part and therefore the input and output of heavy metals in their organisms are clearly reflected through milk. Monitoring the route of heavy metals in relation soilfodder-milk is important since the consequences of their activity have a great impact Issued by The Egyptian Society of Animal Production 
on both environment and people's health (Sharma, 1980; Markert and Friese, 2000 and Vidovic et al., 2003).

Hair has been increasingly used as an index of exposure to heavy metals and has some advantages over blood tests since it is non-invasive, stress less and the concentration of elements in hair tissue is much higher than in body fluids, which simplifies analytical procedures and reduces the possibility of contamination (Krejpcio and Gawęcki, 2002). Recently, trace elements including rare earth elements have begun to be used in large amounts for advanced industries. These are expected to be discharged into surface waters or drainaged (industrial, agricultural and human) into lakes causing harmful effects on aquatic life. Burullus Lake has a great importance based on the different uses of the lake and its surroundings, namely recreation, tourism, fisheries, industrial water source, etc (Diab et al., 2006).

The aim of the present study was to examine the accumulation of heavy metals (lead, cadmium, copper, nikel, aluminum, arsenic and mercury) in hair, plasma and milk of dairy cattle and buffaloes grazing reed plants at Burullus Lake, North Delta, Egypt.

\section{MATERIALS AND METHODS}

\section{Experimental Animals and Sampling}

The current work was carried out at North Delta of Egypt. Twenty four dairy cows and buffaloes were divided in two locations with 6 dairy cows and 6 dairy buffaloes in each. The animals in the first location were fed berseem irrigated by Nile water, while in the second location (Burullus Lake) they grazed reed plants.

Hair, plasma and milk samples were taken from the experimental animals at Burullus Lake to study the effect of grazing reed plants on the content of heavy metals (lead, cadmium, copper, nickel, aluminum, arsenic and mercury) in comparison with those fed berseem from the land irrigated with fresh Nile water. Samples of berseem, reed plants, hair, plasma and milk were prepared for heavy metals determination according to the methods of AOAC (1995) as follows:-

Hair samples were collected from the upper right or lift cage for each animal by a clean shaving tackle close to the skin surface of the animal in clean nylon bag. Each sample was thoroughly washed by tap water, and then rinsed with distilled and boiled distilled water until both the filter and filtrate appeared clear. Hair samples were dried in the oven at $60{ }^{\circ} \mathrm{C}$ for 72 hours, then weighed into crucibles and ashed for 5 hours at $500{ }^{\circ} \mathrm{C}$. Ten $\mathrm{ml} \mathrm{HCL}(10 \%)$ was added to ash and diluted by $15 \mathrm{ml}$ distilled water and then placed on hot plate until the solution completely evaporated. Thereafter, $10 \mathrm{ml} \mathrm{HCL}(10 \%)$ was added and the solution was heated to observe ascending vapors (about $80-90{ }^{\circ} \mathrm{C}$ ), following filtration in volumetric flask $(50 \mathrm{ml})$, transferred into bottles and kept for heavy metals determination.

Blood samples were taken from the jugular vein by clean sterile needle in clean dry plastic tubes using heparin as an anticoagulant. Then centrifuged at 4000 rotations per minute for 15 minute to obtain plasma. One $\mathrm{ml}$ of each plasma sample was wet ashed by using $5 \mathrm{ml}$ pure sulphuric acid and $2.5 \mathrm{ml}$ of pure nitric acid, diluted to $50 \mathrm{ml}$ by distilled water and kept for heavy metals determination.

Milk samples from the evening and morning milkings for each animal were thoroughly mixed. After that, a $5 \mathrm{ml}$ sample was wet ashed in a similar manner to blood plasma samples and kept for heavy metals determination. 


\section{Berseem and reed plants Samples}

The samples of berseem and reed plants were dried at $60{ }^{\circ} \mathrm{C}$ for 72 hours and ground, then ashed for 5 hours at $500{ }^{\circ} \mathrm{C}$ and solubilized as previously described in hair and kept for heavy metals determination.

\section{Determination of heavy metals}

Heavy metals in berseem, reed plants, hair, plasma and milk samples were determined by Atomic Absorption Spectrophotometer (Perkin Elmer 2380).

\section{Statistical analysis}

The data of heavy metals content was statistically analyzed using general liner models procedure adapted by SPSS (2004) for user's guide with one-way ANOVA. Duncan test within program SPSS was used to determine the degree of significance between the means.

\section{RESULTS AND DISCUSSION}

\section{Heavy metals contents in berseem and reed plants:}

Data in Table (1) showed that the contents of heavy metals in reed plants were significantly higher $(\mathrm{P}<0.01)$ than in berseem. The contents of heavy metals in reed plants increased by $48.35,51.35,44.86,34.93,49.40,46.49$ and $45.71 \%$ for $\mathrm{Pb}, \mathrm{Cd}$, $\mathrm{Cu}, \mathrm{Ni}, \mathrm{Al}, \mathrm{Ar}$ and $\mathrm{Hg}$ compared with berseem, respectively. The higher contents of heavy metals in reed plants could be attributed to the sewage sludge presented in water of Burullus Lake. The contents of $\mathrm{Cd}$ and $\mathrm{Hg}$ in reed plants were higher than the maximum tolerable levels of these elements by cattle being 0.5 and $2 \mathrm{ppm}$, respectively (NRC, 1980). The contents of $\mathrm{Pb}, \mathrm{Cu}, \mathrm{Ni}, \mathrm{Al}$ and $\mathrm{Ar}$ in reed plants are within the maximum tolerable levels of these elements by cattle being 30,100, 50, 1000 and $50 \mathrm{ppm}$, respectively (NRC, 1980). These results are within the values obtained by Parkpian et al. (2003). When sewage sludge is surface-applied to grassland, herbage may become contaminated with heavy metals from adhering solids, posing a risk to the health of grazing livestock and possibly increasing the entry of heavy metals into food products (Klessa and Desira-Buttigieg, 1992). Diab et al. (2006) found higher contents of heavy metals $(\mathrm{Cd}, \mathrm{Cr}, \mathrm{Co}, \mathrm{Cu}, \mathrm{Mn}, \mathrm{Ni}, \mathrm{Pb}$ and $\mathrm{Zn}$ ) in water and sediment samples taken from Burullus Lake.

Table 1. Heavy metals contents (ppm on DM basis) in berseem and reed plants

\begin{tabular}{lcccc}
\hline \multicolumn{1}{c}{ Elements } & Berseem & Reed plants & SEM & P value \\
\hline Lead $(\mathrm{Pb})$ & 4.55 & 6.75 & 0.43 & 0.01 \\
Cadmium $(\mathrm{Cd})$ & 0.37 & 0.56 & 0.03 & 0.01 \\
Copper $(\mathrm{Cu})$ & 10.70 & 15.50 & 0.73 & 0.01 \\
Nickel $(\mathrm{Ni})$ & 1.46 & 1.97 & 0.08 & 0.01 \\
Aluminum $(\mathrm{Al})$ & 4.15 & 6.20 & 0.31 & 0.01 \\
Arsenic $(\mathrm{Ar})$ & 5.70 & 8.35 & 0.41 & 0.01 \\
Mercury $(\mathrm{Hg})$ & 1.75 & 2.55 & 0.12 & 0.01 \\
\hline
\end{tabular}

Heavy metals contents in hair:

The contents of heavy metals in hair of cattle and buffaloes fed berseem and reed plants are presented in Table (2). The contents of heavy metals in hair of cattle and buffaloes grazed reed plants were significantly higher $(\mathrm{P}<0.01)$ than in hair of those 
fed berseem. The contents of heavy metals in hair increased by $61.57 \%$ for $\mathrm{Pb}$, $61.59 \%$ for $\mathrm{Cd}, 63.81 \%$ for $\mathrm{Cu}, 53.13 \%$ for $\mathrm{Ni}, 59.80 \%$ for $\mathrm{Al}, 57.22 \%$ for $\mathrm{Ar}$ and $65.55 \%$ for $\mathrm{Hg}$ when animals were grazed reed plants compared with those fed berseem. The high positive correlations between the contents of $\mathrm{Pb}, \mathrm{Cd}, \mathrm{Cu}, \mathrm{Ni}, \mathrm{Al}$, $\mathrm{Ar}$ and $\mathrm{Hg}$ in berseem and reed plants and its contents in hair were 0.86, 0.85, 0.94, $0.82,0.84,0.85$ and 0.81 , respectively. These results are in accordance with those obtained by Rashed and Soltan (2005) who found that heavy metal concentrations in hair reflect the presence of these metals in the surrounding forage and soil and vary from one area to another, and give knowledge about pollution in the area. Correlation statistics analysis and cluster analysis showed good and significant values between metals concentrations in hair and plants. Draghici et al. (2002) concluded that hair can be used as biological marker of pollution and that regular chemical tests of hair can provide information on the level of heavy metals in the body tissues.

Table 2. Effect of feeding berseem and reed plants on heavy metals contents (ppm on DM basis) in hair of cattle and buffaloes

\begin{tabular}{lccccccc}
\multicolumn{1}{c}{ Item } & Pb & $\mathbf{C d}$ & $\mathbf{C u}$ & $\mathbf{N i}$ & $\mathbf{A l}$ & $\mathbf{A r}$ & $\mathbf{H g}$ \\
\hline Feeding & & & & & & & \\
Berseem & 24.20 & 2.76 & 8.51 & 4.16 & 4.08 & 1.94 & 5.95 \\
Reed plants & 39.10 & 4.46 & 13.94 & 6.37 & 6.52 & 3.05 & 9.85 \\
SEM & 1.51 & 0.16 & 0.46 & 0.26 & 0.20 & 0.10 & 0.37 \\
P value & 0.01 & 0.01 & 0.01 & 0.01 & 0.01 & 0.01 & 0.01 \\
Animals & & & & & & & \\
Cattle & 34.90 & 3.96 & 12.18 & 5.81 & 5.73 & 2.70 & 8.68 \\
Buffaloes & 28.40 & 3.26 & 10.27 & 4.72 & 4.87 & 2.29 & 7.12 \\
SEM & 3.37 & 0.38 & 1.23 & 0.50 & 0.55 & 0.25 & 0.89 \\
P value & 0.05 & 0.05 & 0.05 & 0.05 & 0.05 & 0.05 & 0.05 \\
\hline
\end{tabular}

Moreover, the contents of heavy metals were significantly higher $(\mathrm{P}<0.05)$ in hair of cattle compared with buffaloes (Table 2). The contents of heavy metals in hair of cattle increased by $22.89 \%$ for $\mathrm{Pb}, 21.47 \%$ for $\mathrm{Cd}, 18.60 \%$ for $\mathrm{Cu}, 23.09 \%$ for $\mathrm{Ni}$, $17.66 \%$ for $\mathrm{Al}, 17.90 \%$ for $\mathrm{Ar}$ and $21.91 \%$ for $\mathrm{Hg}$ compared with buffaloes. These results may be attributed to the minerals content in hair, which were closely related with the content of melanin black pigment of hair. These results are within the values obtained by Patrashkov et al. (2003) and agreed with those obtained by Gaafar (1994) and Abdel-Raouf et al. (1994) who reported that minerals contents were higher in black hair of Friesian cows than buffaloes.

\section{Heavy metals concentrations in plasma}

The concentrations of heavy metals in plasma of cattle and buffaloes are presented in Table (3). The concentrations of heavy metals in plasma of cattle and buffaloes grazed reed plants were significantly higher $(\mathrm{P}<0.01)$ than of feeding berseem. The concentrations in heavy metals in plasma of cattle and buffaloes grazed reed plants increased by $47.75 \%$ for $\mathrm{Pb}, 48.41 \%$ for $\mathrm{Cd}, 48.17 \%$ for $\mathrm{Cu}, 38.12 \%$ for $\mathrm{Ni}, 43.30 \%$ for $\mathrm{Al}, 49.01 \%$ for $\mathrm{Ar}$ and $42.31 \%$ for $\mathrm{Hg}$ than in those fed berseem. The high positive correlations between the contents of $\mathrm{Pb}, \mathrm{Cd}, \mathrm{Cu}, \mathrm{Ni}, \mathrm{Al}, \mathrm{Ar}$ and $\mathrm{Hg}$ in berseem and reed plants and its concentrations in plasma were $0.87,0.76,0.88,0.86$, $0.85,0.88$ and 0.87 , respectively. Similar results obtained by Gaafar et al. (2005) 
who found that the concentrations of heavy metals in plasma of Friesian calves increased with increasing their contents in ration.

Moreover, the concentrations of heavy metals in plasma of buffaloes were significantly higher $(\mathrm{P}<0.05)$ than cattle (Table 3$)$. The concentrations of heavy metals in plasma of buffaloes increased by $28.11 \%$ for $\mathrm{Pb}, 25.17 \%$ for $\mathrm{Cd}, 23.81 \%$ for $\mathrm{Cu}, 19.13 \%$ for $\mathrm{Ni}, 22.76 \%$ for $\mathrm{Al}, 26.94 \%$ for $\mathrm{Ar}$ and $21.98 \%$ for $\mathrm{Hg}$ than cattle. These results agreed with those obtained by Gaafar (1994) and Abdel-Raouf et al. (1994) who reported that minerals concentrations in plasma of buffaloes were higher than in cows.

Table 3. Effect of feeding berseem and reed plants on heavy metals concentrations $(\mathrm{ug} / 100 \mathrm{ml})$ in plasma of cattle and buffaloes

\begin{tabular}{lccccccc}
\hline \multicolumn{1}{c}{ Item } & $\mathbf{P b}$ & $\mathbf{C d}$ & $\mathbf{C u}$ & $\mathbf{N i}$ & $\mathbf{A l}$ & $\mathbf{A r}$ & $\mathbf{H g}$ \\
\hline Feeding & & & & & & & \\
Berseem & 5.11 & 1.26 & 81.8 & 4.04 & 18.87 & 5.04 & 5.27 \\
Reed & 7.55 & 1.87 & 121.20 & 5.58 & 27.04 & 7.51 & 7.58 \\
plants & & & & & & & \\
SEM & 0.78 & 0.18 & 10.80 & 0.42 & 2.35 & 0.75 & 0.48 \\
P value & 0.01 & 0.01 & 0.01 & 0.01 & 0.01 & 0.01 & 0.01 \\
Animals & & & & & & & \\
Cattle & 5.55 & 1.39 & 90.70 & 4.39 & 20.61 & 5.53 & 5.93 \\
Buffaloes & 7.11 & 1.74 & 112.30 & 5.23 & 25.30 & 7.02 & 6.92 \\
SEM & 1.22 & 0.31 & 19.70 & 0.77 & 4.09 & 1.24 & 1.17 \\
P value & 0.05 & 0.05 & 0.05 & 0.05 & 0.05 & 0.05 & 0.05 \\
\hline
\end{tabular}

\section{Heavy metals contents in milk}

The contents of heavy metals in milk of cattle and buffaloes are shown in Table (4). The contents of heavy metals in milk of cattle and buffaloes grazed reed plants were significantly higher $(\mathrm{P}<0.01)$ than those animals, which were fed berseem. The contents in heavy metals in milk of cattle and buffaloes grazed reed plants increased by $48.72 \%$ for $\mathrm{Pb}, 46.15 \%$ for $\mathrm{Cd}, 45.96 \%$ for $\mathrm{Cu}, 46.81 \%$ for $\mathrm{Ni}, 44.88 \%$ for $\mathrm{Al}$, $45.71 \%$ for $\mathrm{Ar}$ and $44.00 \%$ for $\mathrm{Hg}$ than those fed berseem. The high positive correlations between the contents of $\mathrm{Pb}, \mathrm{Cd}, \mathrm{Cu}, \mathrm{Ni}, \mathrm{Al}, \mathrm{Ar}$ and $\mathrm{Hg}$ in berseem and reed plants and its contents in milk were $0.88,0.84,0.85,0.85,0.80,0.88$ and 0.87 , respectively. These results are in agreement with those obtained by Sharma et al. (1982) who found that low dietary intake of heavy metals do not produce an appreciable rise of these metals in edible products, e.g., milk. Parkpian et al. (2003) reported that improvements of farm management give significant reduction in elevated levels of $\mathrm{Pb}$ and $\mathrm{Cd}$ in soil and plants, and however leads to minimize the amount of $\mathrm{Pb}$ and $\mathrm{Cd}$ in produced milk. El-Gazaly and Sallam (2002) indicated higher heavy metals contents in milk of cows and buffaloes exist in contaminated areas.

Moreover, the contents of heavy metals in milk of buffaloes were significantly higher $(\mathrm{P}<0.05)$ than cattle (Table 4$)$. The contents of heavy metals in milk of buffaloes increased by $25.58 \%$ for $\mathrm{Pb}, 28.57 \%$ for $\mathrm{Cd}, 24.90 \%$ for $\mathrm{Cu}, 27.45 \%$ for $\mathrm{Ni}, 24.11 \%$ for $\mathrm{Al}, 25.00 \%$ for $\mathrm{Ar}$ and $25.93 \%$ for $\mathrm{Hg}$ than cattle. The higher contents of heavy metals in buffalo's milk could be attributed to its higher ash content compared with cow's milk. In this connection, El-Gazaly and Sallam (2002) reported 
that the contents of heavy metals were higher in buffalo's milk than those of cow's milk.

Table 4. Effect of feeding berseem and reed plants on heavy metals contents (ppm on fresh basis) in milk of cattle and buffaloes

\begin{tabular}{lccccccc}
\multicolumn{1}{c}{ Item } & Pb & $\mathbf{C d}$ & $\mathbf{C u}$ & $\mathbf{N i}$ & $\mathbf{A l}$ & $\mathbf{A r}$ & $\mathbf{H g}$ \\
\hline Feeding & & & & & & & \\
Berseem & 0.39 & 0.26 & 2.35 & 0.47 & 2.05 & 0.70 & 0.50 \\
Reed plants & 0.58 & 0.38 & 3.43 & 0.69 & 2.97 & 1.02 & 0.72 \\
SEM & 0.06 & 0.04 & 0.32 & 0.07 & 0.27 & 0.10 & 0.07 \\
P value & 0.01 & 0.01 & 0.01 & 0.01 & 0.01 & 0.01 & 0.01 \\
Animals & & & & & & & \\
Cattle & 0.43 & 0.28 & 2.57 & 0.51 & 2.24 & 0.76 & 0.54 \\
Buffaloes & 0.54 & 0.36 & 3.21 & 0.65 & 2.78 & 0.96 & 0.68 \\
SEM & 0.10 & 0.06 & 0.54 & 0.11 & 0.46 & 0.16 & 0.11 \\
P value & 0.05 & 0.05 & 0.05 & 0.05 & 0.05 & 0.05 & 0.05 \\
\hline
\end{tabular}

\section{CONCLUSION}

From these results it could be concluded that grazing cattle and buffaloes on reed plants in Burullus Lake led to higher accumulation of heavy metals in their hair, blood plasma and milk, causing possible hazardous effect on human health.

\section{REFERENCES}

Abdel-Raouf, E.M., M.K. Mohsen, S.A. Mahmoud and H.M.A. Gaafar, 1994. Hair and blood plasma as indicators of mineral status in cattle and buffaloes. J. Agric. Sci. Mansoura Univ., 19: 103.

AOAC, 1995. Official Methods of Analysis (16 ${ }^{\text {th }}$ Ed.). Association of Official Analytical Chemists, Arlington, USA.

Diab, H.M., A.B. Ramadan and M.H.E. Monged, 2006. Assessment of natural radioactivity and heavy metals in Burullus Lake, Egypt. International J. of Low Radiation, 3: 273.

Draghici, C., D. Crisan, S. Eftimie and V. Pop, 2002. The presence and persistence of heavy metals in the hair of cattle raised within the industrially polluted area of Baia Mare. Seria Medicina Veterinara, 58: 185.

El-Gazaly, F.M. and M.T. Sallam, 2002. Lead, cadmium and aluminum concentration levels in raw milk of lactating cows and buffaloes raised in localities under different ecological conditions in middle Egypt. $1^{\text {st }}$ Ann. Sc. Conf. Anim. \& Fish Prod. Mansoura, 24\&25 Sep., p. 48.

Fergusson, E., 1990. The heavy elements: Chemistry, environmental impact and health effects. Pergamon press, Oxford, p. 461.

Gaafar, H.M.A., 1994. Metabolism of some minerals in cattle and buffaloes. M. Sc. Thesis, Faculty of Agric., Kafr El-Shiekh, Tanta Univ.

Gaafar, H.M.A., R.M. Abou-Aiana, G.H.A. Ghanem and Mona A. Ali, 2005. Accumulation of some heavy metals and histological aspects of body tissues of 
growing Friesian calves fed poultry litter and corn silage. Egyptian J. Anim. Prod., 42: 95.

Klessa, D.A. and A. Desira-Buttigieg, 1992. The adhesion to leaf surfaces of heavy metals from sewage sludge applied to grassland. Soil Use and Management, 8: 115.

Krejpcio, Z. and J. Gawęcki, 2002. Hair lead and body lead burden in leadintoxicated rats fed diets enriched with dietary fiber. Polish Journal of Environmental Studies, 11: 123.

Markert, B. and K. Friese, 2000. Trace Elements. Their Distribution and Effects in the Environment. ( $1^{\text {st }}$ Ed.). Elsevier, Oxford.

NRC, 1980. Mineral Tolerance of Domestic Animals. National Academy Press. Washington, D.C.

Pais, I., 1992. Az általánosan létfontosságú mikroelemek (A mikroelemek korszaka) (Essencially microelements). Biokémia, p. 352.

Parkpian, P., S.T. Leong, P. Laortanakul and N. Thunthaisong, 2003. Regional monitoring of lead and cadmium contamination in a tropical grazing land site, Thailand. Environmental monitoring and assessment, 85: 157.

Patrashkov, S.A., V.L. Petukhov, O.S. Korotkevich and I.V. Petukhov, 2003. Content of heavy metals in the hair. J. Phys. IV France, 107: 1025.

Pittia, P., 1992. Indagine sul contenuto in piombo in latte della Provincia di Udine (The content of lead in milk from the Province of Udine). Scienza e Tecnica Lattiero Casearia, 43: 201.

Rashed, M. and M. Soltan, 2005. Animal hair as biological indicator for heavy metal pollution in urban and rural areas. Environmental Monitoring and Assessment, 110: 41.

Sharma, R.P., 1980. Soil-plant-animal distribution of cadmium in the environment. In "Cadmium in the Environment". (J. O. Nriagu, Ed.), p. 587-605. Wiley, New York.

Sharma, R.P., J.C. Street, J.L. Shupe and D.R. Bourcier, 1982. Accumulation and depletion of cadmium and lead in tissues and milk of lactating cows fed small amounts of these metals. J. Dairy Sci., 65: 972.

Smith, R.M., R.M. Leach, L.D. Mulles, L.C. Griel, Jr. and D.E. Bakefi, 1991. Effects of long-term dietary cadmium chloride on tissue, milk, and urine mineral concentrations of lactating dairy cows. J. Anim. Sci., 69: 4088.

SPSS for windows, 2004. Statistical package for the social sciences, Release 13, SPSS INC, Chicago, USA.

Ure, A.M. and M.L. Berrow 1982. Berrow: The elemental constituents of soil. In" Reporter, Environmental Chemistry. (H. J. M. Bowen, Ed.), Roy. Soc., 1: 142.

Vidovic, M.M., U.M. Vidovic and N.M. Rodic, 2003. Heavy metals in relation to soil- fodder-milk. http://www.Prague 2003.fsu. edu/content/pdf/606.pdf

Webber, J., 1981. Trace metals in agriculture. In"Effect of Heavy Metal Pollution on Plants". (N. W. Lepp, Ed.), Appl. Sci. Publ., 2: 159. 
تراكم بعض العناصر الثقيلة فى شعر، بلازما ولبن الأبقار والجاموس التى ترعى على البرسيم ونباتات الغاب فى مصر الغنر

حامد محمد عبد المجيل جعفر

معرج بحوث الاتتاج الحيوانى، مركز البحوث الزراعية، الدقى، مصر

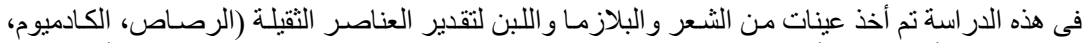

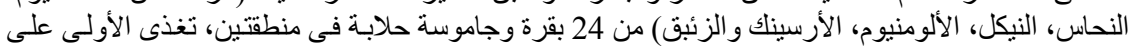
البرسيم الذى يروى بمياة النيل بينما ترى الثانية على نباتات الغاب ببحيرة البرلس حيث فيث تضم كل منطقة 6 أبقار

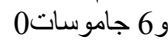

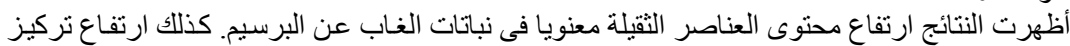

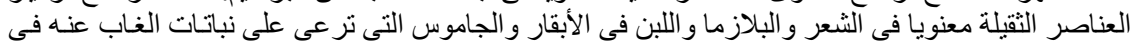

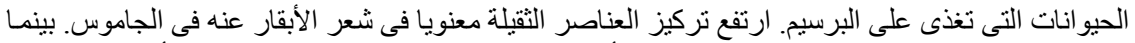

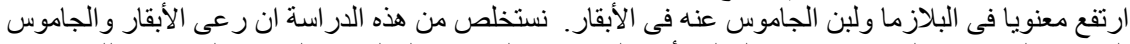

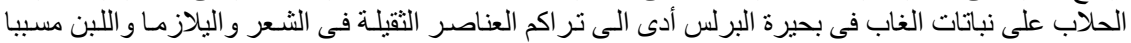

